\title{
Diet and weaning age affect the growth and condition of Dover sole (Solea solea L.)
}

\section{La dieta y la edad de destete afectan el crecimiento y la condición del sol común (Solea solea L.)}

\author{
Rebeca A. Rueda-Jasso ${ }^{1 *}$ \\ Luis E.C. Conceição \\ Wim De Coen ${ }^{3}$ \\ Jean Francois Rees ${ }^{4}$ \\ Patrick Sorgeloos ${ }^{1}$ \\ ${ }^{1}$ Laboratory of Aquaculture and Artemia Reference Center \\ Ghent University \\ Rozier 44 \\ B 9000 Gent, Belgium \\ *E-mail: Rebeca_Aneli@yahoo.com \\ ${ }^{2}$ CCMAR Centre of Marine Sciences \\ University of Algarve \\ Campus de Gambelas \\ 8000-117 Faro, Portugal \\ ${ }^{3}$ Laboratory for Ecophysiology, Biochemistry and Toxicology \\ University of Antwerp \\ B 2020 Antwerp, Belgium \\ ${ }^{4}$ Animal Biology Unit \\ Catholic University of Louvain \\ B 1348 Louvain-la-Neuve, Belgium
}

Recibido en julio de 2004; aceptado en abril 2005

\begin{abstract}
The effect of diet type (frozen Artemia biomass and two inert diets: micro-bound [MB] and micro-extruded [ME]) and two weaning ages (early weaning and late weaning, 50 and 64 days after hatching, respectively) were studied in Solea solea larvae. The experiment lasted 56 and 42 days for early and late weaning, respectively. The mortality results showed the highest values for late weaning (39\%) in the Artemia treatment. No significant differences in mortality were observed between the inert diets. The final dry weight values were higher for late weaning than for early weaning. At both weaning ages, fish receiving the same treatments had similar tendencies for dry weight and standard length. Fish fed with MB presented significantly higher dry weight and standard length, followed by ME, while the lowest values at both weaning ages were recorded for the Artemia treatment. Similar amounts of highly unsaturated fatty acid fractions among the inert diets were reflected by the absence of significant differences in the susceptibility to oxidation (thiobarbituric acid reactive substances testing); however, significant differences were found in carbohydrate, protein and lipid contents of whole-body homogenates for both early and late weaning. At the end of the experiment no significant differences in biochemical contents were observed between the two inert diets. The results of this study suggest that weaning starting on day 50 (early weaning), using a good quality inert diet, leads to higher survival, growth and fish condition.
\end{abstract}

Key words: Dover sole, larvae, weaning, inert diets, Artemia.

\section{Resumen}

Se estudiaron los efectos del tipo de dieta (biomasa de Artemia congelada y dos dietas inertes: una micro-compactada [MB] y una micro-extruida [ME]) y dos edades de destete (temprana y tardía, a 50 y 64 días de edad después de la eclosión, respectivamente) en larvas de Solea solea. El experimento duró 56 y 42 días para el destete temprano y tardío, respectivamente. Los mayores valores de mortalidad se presentaron con el tratamiento Artemia en destete tardío (39\%). No se observaron diferencias significativas en la mortalidad entre dietas inertes. Los valores finales de peso seco fueron mayores para el destete 
tardío que para el temprano. Independientemente de la edad de destete, los peces que recibieron la misma dieta mostraron tendencias similares en peso seco y longitud estándar. Los peces alimentados con MB presentaron peso seco y longitud estándar significativamente mayores, seguidos por los alimentados con ME, en tanto que el tratamiento con Artemia alcanzó los valores más bajos. El hecho de que las dietas inertes presentaran fracciones similares de ácidos grasos altamente insaturados quedó reflejado en la ausencia de diferencias significativas en la susceptibilidad a la oxidación (prueba de substancias reactivas al ácido tiobarbitúrico). Sin embargo, sí se encontraron diferencias significativas en los contenidos de carbohidratos, proteinas y lípidos medidos en los homogeneizados de pescado completo tanto para el destete temprano como para el tardío. Al final del experimento no se observaron diferencias significativas en los contenidos bioquímicos de los organismos sometidos a ambas dietas inertes. Los resultados de este estudio sugieren que un destete temprano (día 50), usando una dieta inerte de buena calidad, conduce a mayores tasas de supervivencia, crecimiento y condición del pez.

Palabras clave: sol común, larva, destete, dietas inertes, Artemia.

\section{Introduction}

The Dover sole Solea solea L. is one of the most consistently high-priced fish throughout most of Europe. Metamorphosis and weaning of sole larvae are critical periods for the cultivation of this species, and are normally accompanied by increased mortality. Various types of diets and methods have been tested for weaning Dover sole. Some include the utilization of live prey such as Artemia nauplii, which increases production costs. Others have been mainly based on providing fresh ingredients in wet pastes and/or pellets containing attractive compounds (Metailler et al., 1981). Weaning can be either progressive (co-feeding) or short-term. Early weaning, starting immediately after metamorphosis, has resulted in higher mortality and a slow growth (Person-Le Ruyet, 1984). A successful weaning diet should take into consideration the larva's mouth size, feeding behaviour and nutritional requirements, and food palatability and stability in water.

The physiological response of an organism can be affected by nutritional, genetic or physico-chemical factors. It is known that nutritional components can influence the oxidation levels and antioxidant defences in animal tissues (Tocher et al., 2002a, b). Lipid and polyunsaturated fatty acids (PUFA) are implicated in peroxidation, while dietary micronutrients such as vitamin $\mathrm{E}$ act as antioxidant protection. Under normal physiological conditions animal cells produce reactive oxygen species (ROS). At the same time, antioxidant defences are produced and their function is to cope with ROS; however, an unbalance between the antioxidant defences and ROS can occur, producing oxidative stress (Tocher et al., 2002b). The ROS can oxidize most cellular constituents such as DNA, proteins and lipids (Janssens et al., 2000), causing damage, cross-linking and the decline of the cellular integrity by reducing enzyme activities. Fish tissues, especially bio-membranes and fish diets, are typically rich in n-3 PUFA, which are highly susceptible to oxidation.

The susceptibility to oxidation of fish tissues should be considered when designing appropriate diets for the initial larval stages and weaning. This is especially important given that the source of dietary energy (either digestible protein, lipids or carbohydrates) can affect lipid oxidation, as shown in muscle homogenates of rainbow trout and European seabass (Alvarez et al., 1998, 1999; López-Bote et al., 2001).

\section{Introducción}

El sol común Solea solea L. se ha caracterizado por ser un producto de precio elevado en gran parte de Europa. La metamorfosis y el destete de la larva de sol son periodos críticos para el cultivo de esta especie, los cuales normalmente van acompañados de un incremento de mortalidad. Se han probado varios tipos de dietas y métodos de destete para el sol común; algunos incluyen la utilización de presas vivas como nauplios de Artemia, lo cual incrementa los costos de producción. Otros métodos se basan en suministrar ingredientes frescos en forma de pastas húmedas y/o pelets que contienen compuestos atrayentes (Metailler et al., 1981). El destete puede ser progresivo (coalimentación) o mediante un cambio radical de dieta. El destete temprano, inmediatamente después de la metamorfosis, genera una mortalidad elevada y un crecimiento lento (PersonLe Ruyet, 1984). Para lograr una dieta de destete exitosa es necesario considerar aspectos tales como el tamaño de la boca del pez, la conducta alimenticia, la palatibilidad, los requerimientos nutricionales de la larva y la estabilidad del alimento en el agua.

La respuesta fisiológica de un organismo puede verse afectada por factores fisicoquímicos, nutricionales y/o genéticos. Se sabe que los componentes nutricionales pueden influir sobre los niveles de oxidación y sobre las defensas antioxidantes en los tejidos animales (Tocher et al., 2002a, b). Los lípidos y los ácidos grasos poliinsaturados (PUFAs) están implicados en la peroxidación, en tanto que los micronutrientes tales como la vitamina E actúan como una protección antioxidante. En condiciones fisiológicas normales las células animales producen especies reactivas al oxígeno (ROS). Al mismo tiempo, se generan defensas antioxidantes cuya función es proteger de las ROS. Sin embargo, cuando se produce un desequilibrio entre las denfensas antioxidantes y las ROS, puede producirse un estrés oxidativo (Tocher et al., 2002b). Las ROS pueden oxidar a la mayoría de los componentes celulares tales como DNA, proteínas y lípidos (Janssens et al., 2000) causando daños, cross-linking y desintegración celular, debido a la reducción de la actividad enzimática. Los tejidos de los peces, especialmente las biomembranas, así como sus dietas, son típicamente ricos en PUFAs n-3, los cuales son muy suceptibles a la oxidación.

El diseño de dietas adecuadas para las etapas larvales iniciales y el destete, debe considerar la suceptibilidad a la 
The purpose of this study was to evaluate the effect of the diet (two inert diets and frozen Artemia) and the weaning start age (early and late weaning) on growth, survival, condition and oxidative status, in order to improve the weaning of Dover sole under culture conditions.

\section{Materials and methods}

\section{Egg and larval culture conditions}

The broodstock were maintained at the laboratory of the Fisheries Department in Oostende, Belgium (temperature of $9 \pm 2^{\circ} \mathrm{C}$, 200 lumen $\mathrm{m}^{-2}$ continuous illumination measured at the water surface and bottom aeration). The fish were fed fresh mussels on a daily basis. When spawning occurred, the eggs were collected and transported to the Laboratory of Aquaculture and Artemia Reference Center, where the eggs were placed in 70-L cylindro-conical tanks and incubated at $15^{\circ} \mathrm{C}$ in an open flow-through system with a water renewal rate of $80-100 \%$ per hour.

The start of hatching was considered day zero. The chorion, unfertilized eggs and dead larvae that sank were carefully removed by siphoning to avoid water quality deterioration. On day 3 after hatching, larvae were first fed rotifers at a density of 2 ind $\mathrm{mL}^{-1}$, gradually increasing to 8 ind $\mathrm{mL}^{-1}$. On day 7 the larvae started to feed on enriched Artemia metanauplii, from an initial density of 0.5 to 7 metanauplii $\mathrm{mL}^{-1}$ on day 22. Larvae were fed twice a day, in the morning and in the evening. Artemia metanauplii were enriched for $24 \mathrm{~h}$ with an experimental Selco emulsion (Selco DHA/EPA $=4$; INVE Aquaculture, N.V. Belgium), containing $10 \%$ vitamin C. Before each feeding, three 10 -mL samples were taken from the rearing tanks and uneaten rotifer and nauplii were evaluated and the density was re-established. From day 28 after hatching to the beginning of the experiment, the larvae were fed ad libitum with on-grown Artemia. The $\mathrm{NH}_{4}{ }^{+}, \mathrm{NO}_{2}{ }^{-}$and $\mathrm{NO}_{3}{ }^{-}$concentrations in the water of the rearing tanks were evaluated three times per week.

\section{Experimental design}

Three treatments consisting of two inert diets and frozen Artemia biomass were tested in three replicates at two weaning ages, 50 and 64 days after hatching (DAH). The two experiments at different weaning ages were conducted independently. One of the diets was of the micro-bound (MB) type (SSF, Norwegian Herring and Oil Res. Industry, Norway), while the other was a micro-extruded (ME) diet (an experimental product of INVE Aquaculture, N.V. Belgium). The analyses of ash, moisture and crude protein for the three diets (table 1) were done following the AOAC (1984) procedures, and the total lipid content and highly unsaturated fatty acid (HUFA) profiles (table 1) were determined using standard analytical methods. Lipids were extracted according to Folch et al. (1957), following the modification of Ways and Hanahan oxidación de los tejidos de los peces. Esto es de especial importancia dado que la fuente dietética de energía (proteínas, lípidos o carbohidratos) puede afectar la oxidación de los lípidos, tal y como ha sido observado en los homegeneizados de trucha arcoiris y de lubina (Álvarez et al., 1998, 1999; López-Bote et al., 2001).

El propósito del presente estudio fue evaluar el efecto de la dieta (dos dietas inertes y biomasa de Artemia congelada) y dos edades de inicio del destete (destete temprano y tardío) sobre el crecimiento, supervivencia, condición y estado de oxidación, con el fin de mejorar el destete del sol común en condiciones de cultivo.

\section{Materiales y métodos}

\section{Condiciones de cultivo de huevos y larvas}

Los reproductores se mantuvieron en el Laboratorio del Departamento de Pesquerías de Oostende, Bélgica $\left(9 \pm 2^{\circ} \mathrm{C}\right.$ de temperatura, 200 lumen $\mathrm{m}^{-2}$ de iluminación continua medida en la superficie del agua y aireación de fondo). Los peces fueron alimentados diariamente con mejillones frescos. Los huevos se recolectaron al desovar los peces y se transportaron al Laboratorio de Acuacultura y Centro de Referencia Artemia (ARC). En el ARC, los huevos se colocaron en tanques cilindro-cónicos ( $70 \mathrm{~L}$ de volumen) y se incubaron a $15^{\circ} \mathrm{C}$ en un sistema con flujo abierto, con una tasa de renovación del agua de $80-100 \%$ por hora.

El inicio de la eclosión fue considerado como día cero. Los corion, huevos sin fertilizar y larvas muertas se extrajeron sifoneando cuidadosamente para evitar el deterioro de la calidad del agua. Se alimentó por primera vez a las larvas tres días después de la eclosión (DAH). Inicialmente se utilizaron rotíferos a una densidad de 2 ind $\mathrm{mL}^{-1}$ aumentando gradualmente hasta 8 ind $\mathrm{mL}^{-1}$. Siete días DAH, se comenzó a alimentar a las larvas con metanauplios de Artemia enriquecidos (densidad inicial 0.5 hasta 7 metanauplios $\mathrm{mL}^{-1}$ el día $22 \mathrm{DAH}$ ). Las larvas se alimentaron dos veces por día, por la mañana y por la tarde. Los metanauplios de Artemia se enriquecieron durante 24 h con una emulsión experimental Selco (Selco DHA/EPA = 4; INVE Aquaculture, N.V. Bélgica), conteniendo un $10 \%$ de vitamina C. Antes de alimentar las larvas se tomaron tres muestras de $10 \mathrm{~mL}$ de los tanques de crianza y se contabilizaron los rotíferos y los nauplios restantes para posteriormente reestablecer las densidades. A partir del día 28 y hasta el principio del experimento, las larvas se alimentaron con Artemia ad libitum. Las concentraciones de $\mathrm{NH}_{4}{ }^{+}, \mathrm{NO}_{2}{ }^{-}$y $\mathrm{NO}_{3}{ }^{-}$en el agua de los tanques de cultivo se evaluaron tres veces por semana.

\section{Diseño experimental}

Se estudio, por triplicado, el efecto de la combinación de tres tratamientos que consistieron en dos dietas inertes y biomasa de Artemia congelada, a dos edades de inicio del destete 
Table 1. Proximal composition ( $\mathrm{g} / 100 \mathrm{~g}$ dry matter) and highly unsaturated fatty acid fractions of the experimental diets used for weaning Solea solea larvae: frozen Artemia and the micro-extruded (ME) and micro-bound (MB) inert diets.

Tabla 1. Composición proximal ( $\mathrm{g} / 100 \mathrm{~g}$ de materia seca) y las fracciones de ácidos grasos altamente insaturados en las dietas experimentales utilizadas para el destete de larvas de Solea solea: Artemia congelada y las dietas inertes micro-extruida (ME) y micro-compactada (MB).

\begin{tabular}{lccr}
\hline & Frozen Artemia & \multicolumn{1}{c}{ ME } & \multicolumn{1}{c}{ MB } \\
\hline Ash & $19.2 \pm 5.3$ & $12.5 \pm 0.2$ & $8.8 \pm 0.1$ \\
Moisture & $*$ & $5.4 \pm 0.3$ & $6.1 \pm 0.2$ \\
Proteins & $58.3 \pm 6.6$ & $63.8 \pm 0.0$ & $59.6 \pm 0.6$ \\
Total lipids & $12.5 \pm 3.4$ & $18.5 \pm 1.4$ & $23.6 \pm 1.8$ \\
18:3 n-3 & $*$ & $2.4 \pm 0.4$ & $3.3 \pm 0.2$ \\
20:5 n-3 & $*$ & $15.4 \pm 2.3$ & $12.2 \pm 1.9$ \\
20:6 n-3 & $*$ & $22.0 \pm 2.2$ & $22.5 \pm 2.7$ \\
Total n-3 & $*$ & $40.9 \pm 4.1$ & $37.6 \pm 4.6$ \\
Total n-6 & $*$ & $16.4 \pm 0.9$ & $13.4 \pm 1.3$ \\
\hline
\end{tabular}

Values of macronutrients are mean percentages of dry weight \pm standard deviation, except moisture. Highly unsaturated fatty acid fractions expressed as mg/g of total lipids. * Not measured.

(1964). Fatty acid methyl ester (FAME) composition was verified by gas chromatography according to Coutteau and Sorgeloos (1995), and identified by a Chrompack CP9001 gas chromatograph equipped with TPOCI (temperature programmable on-column injector). The injections were performed on a polar 50-m capillary column BPX70 (SGE Australia), with a diameter of $0.32 \mathrm{~mm}$ and layer thickness of $0.25 \mu \mathrm{m}$, connected to a 2.5-m methyl deactivated pre-column.

At the beginning of metamorphosis (28 DAH), the larvae were transferred to 35-L flat tanks at a density of 16 larvae $\mathrm{L}^{-1}$. Each tank was connected to an individual biofilter, in a recirculation system, with a water renewal of around $180 \%$ per day. Photoperiod was $12 \mathrm{~L}: 12 \mathrm{D}$, temperature $16 \pm 1.5^{\circ} \mathrm{C}$ and salinity $35 \mathrm{~g} \mathrm{~L}^{-1}$. Remaining food and faeces were siphoned out of the system on a daily basis. Dead animals were counted and removed. The fish were fed manually three to four times per day. For the inert diets, the particle sizes were changed according to the size of the fish's mouth: a pellet size of 200 to $400 \mu \mathrm{m}$ was used from the beginning to $70 \mathrm{DAH}$, of 400 to $600 \mu \mathrm{m}$ from 71 to $90 \mathrm{DAH}$, and of $600 \mu \mathrm{m}$ to $1 \mathrm{~mm}$ from $91 \mathrm{DAH}$ until the end of the experiment (106 DAH). The change to the experimental diets was gradually introduced during three days of co-feeding with Artemia.

A sample of 10 fish per tank was taken at the beginning of the experiment and each week. The individuals were anaesthetized with 0.3-ppm 2-phenoxyethanol and measured for total and standard length, and dry weight. The daily rations of the different diets were calculated as $10 \%$ of body weight per day. The weekly average wet weight data per tank were used to
(50 y 64 DAH) en larvas de sol común. Para ello, se realizaron dos experimentos independientes. Las dietas inertes fueron: una dieta micro-compactada (MB, SSF, Norwegian Herring and Oil Res. Industry, Noruega) y una dieta micro-extruida (ME, producto experimental de INVE Aquaculture, N.V. Bélgica). Los análisis de cenizas, húmedad y proteína cruda de las tres dietas (tabla 1) se realizaron de acuerdo con los procedimientos de AOAC (1984), en tanto que el contenido total de lípidos y las fracciones de ácidos grasos altamente insaturados (HUFAs) (tabla 1) se determinaron usando métodos analíticos estándar. Los lípidos se extrajeron de acuerdo con Folch et al. (1957), siguiendo las modificaciones de Ways y Hanahan (1964). La composición de ácidos grasos metilados (FAMEs) se verificó por cromatografía de gases de acuerdo con Coutteau y Sorgeloos (1995) y las fracciones fueron identificadas en un cromatógrafo de gases Chrompack CP9001 equipado con TPOCI (inyector de columna con temperatura programable). Las inyecciones se realizaron en una columna capilar de $50 \mathrm{~m}$ BPX70 (SGE Australia) con un diámetro de $0.32 \mathrm{~mm}$ y una fase estacionaria de $0.25 \mu \mathrm{m}$ de grosor conectada a una precolumna de metilo desactivado de $2.5 \mathrm{~m}$.

Al principio de la metamorfosis (28 DAH) las larvas se transfirieron a tanques planos (35 L de volumen) a una densidad de 16 larvas $\mathrm{L}^{-1}$. Cada tanque se conectó a un biofiltro individual con un sistema recirculatorio, con una tasa de renovación de $180 \% \mathrm{día}^{-1}$. El fotoperiodo fue de 12L:12O, la temperatura de $16 \pm 1.5^{\circ} \mathrm{C}$ y la salinidad de $35 \mathrm{~g} \mathrm{~L}^{-1}$. Diariamente se sifonearon fuera del sistema el alimento remanente y las heces. Asimismo, se contabilizaron y retiraron las larvas muertas. Los peces se alimentaron manualmente de tres a cuatro veces por día. En el caso de las dietas inertes los tamaños de las partículas se cambiaron de acuerdo al tamaño de la boca del pez. Se utilizarón pelets de 200 a $400 \mu \mathrm{m}$ desde el inicio del experimento hasta $70 \mathrm{DAH}$, de 400 a $600 \mu \mathrm{m}$ de 71 a $90 \mathrm{DAH}$ y de $600 \mu \mathrm{m}$ a $1 \mathrm{~mm}$ de 91 DAH hasta el final del experimento (106 DAH). El cambio a la dieta experimental se realizó gradualmente durante tres días, en los que se alimentó también con Artemia.

Al principio del experimento y cada semana se tomó una muestra de 10 peces por cada tanque. Los individuos se anestesiaron con 2-fenoxietanol a $0.3 \mathrm{ppm}$ y se midieron su longitud estándar y peso seco. Las raciones de las diferentes dietas se calcularon con base a $10 \%$ del peso corporal promedio por día. Los datos del peso húmedo semanal promedio se usaron para calcular la cantidad de alimento que se debía agregar. El cálculo de la ración diaria de Artemia congelada se basó en una evaluación preliminar de la equivalencia de un gramo de biomasa a peso seco

La tasa de crecimiento relativo (RGR, \% $\mathrm{d}^{-1}$ ) se calculó de acuerdo con la fórmula: $\left(\mathrm{e}^{\mathrm{g}-1}\right) \times 100$, donde $\mathrm{g}=\left(\mathrm{Ln} \mathrm{W}_{2}-\mathrm{Ln}\right.$ $\left.\mathrm{W}_{1}\right) /\left(\mathrm{t}_{2}-\mathrm{t}_{1}\right)$. Al final del experimento se anestesiaron y homogeneizaron cuatro peces por tanque para realizar la prueba de sustancias reactivas al ácido tiobarbitúrico (TBARS). Cuatro peces más se utilizaron para medir los contenidos bioquímicos (carbohidratos, proteínas y lípidos). 
calculate the amount of diet to be added. A preliminary evaluation of the equivalence of $1 \mathrm{~g}$ of frozen Artemia to dry weight was done to allow calculation of the frozen Artemia daily ration.

Relative growth rate (RGR) $\left(\% \mathrm{~d}^{-1}\right)$ was calculated according to the formula: RGR $=\left(\mathrm{e}^{\mathrm{g}-1}\right) \times 100$, where $\mathrm{g}=$ $\left(\operatorname{Ln} W_{2}-L n W_{1}\right) /\left(t_{2}-t_{1}\right)$. At the end of the experiment, four fish per tank were anaesthetized and homogenized for thiobarbituric reactive substances (TBARS) testing and four other fish for biochemical contents (carbohydrates, proteins and lipids).

\section{Homogenate preparation}

Samples of 12 fish per treatment were prepared as homogenates for biochemical contents and TBARS tests. The fishes (whole-body) were weighed and their standard length was measured. They were then cut into small pieces and homogenated. The preparation of the homogenates was made using an ice Bain Marie and a four up-and-down strokes Polytron PTA $10 \mathrm{~S}$ homogenizer. A measured volume of buffer (depending on the size of the sample) (0.1 M Tris-HCl pH 8.5, 15\% (w/v) Poly Vinyl Pyrrolidone, $153 \mu \mathrm{M} \mathrm{MgSO}_{4}$ and $0.2 \%(\mathrm{w} / \mathrm{v})$ Triton $\mathrm{X}-100$ ) was added to blend the sample. The volume of buffer used to prepare the homogenates depended on the size of the larvae, varying from 1 to $5 \mathrm{~mL}$ per fish. Homogenated samples were stored at $-80^{\circ} \mathrm{C}$.

\section{TBARS test}

The susceptibility of the whole-body homogenates to induced lipid oxidation was performed by TBARS testing (Janssens et al., 2000). The homogenates were centrifuged and $400 \mu \mathrm{L}$ of $15 \%$ trichloroacetic acid (TCA) and $800 \mu \mathrm{L}$ of thiobarbituric acid (TBA) $(0.67 \%$ diluted in $\mathrm{NaOH}$ solution $0.3 \mathrm{~N}$ ) were added to $500 \mu \mathrm{L}$ of supernatant. After heating $\left(95^{\circ} \mathrm{C}\right)$ for $20 \mathrm{~min}$ and cooling down, an extraction of pigment was induced with the addition of $3 \mathrm{~mL}$ of butanol and centrifugation (2000 rpm, $4^{\circ} \mathrm{C}, 5 \mathrm{~min}$ ). Supernatants were recovered and analyzed in a fluorescence spectrophotometer (Spectramax 190, Molecular Devices, Sunnyvale CA 94089, USA) (Em 555 and Ex 515). The TBARS levels were calculated from a standard curve constructed with malonaldehyde dimethyl acetate (MDA). Results are expressed as moles of MDA mg-1 protein. Protein measurements were carried out applying the methodology of Lowry et al. (1951) and using albumin as standard.

\section{Biochemical analyses}

The measurements of carbohydrates and proteins were made in $200 \mu \mathrm{L}$ of homogenates (Holland and Gabbot, 1971; Bradford, 1976). After the addition of 15\% TCA and centrifugation of the mixture, the pellets were washed with 5\% TCA and both supernatant fractions were combined. Supernatant fractions were used for the carbohydrate determinations, while

\section{Preparación de los homogeneizados}

Para evaluar los contenidos bioquímicos y realizar la prueba de TBARS se prepararon homogeneizados de 12 peces por tratamiento. Los peces (completos) se pesaron y se midió su longitud estándar; se cortaron en trozos pequeños y se homogeneizaron. Para la preparación de los homogeinizados se utilizó un homogeneizador de cuatro velocidades Polytron PTA 10S. Durante el proceso las muestras se mantuvieron en un baño María de hielo. Para ayudar a moler la muestra se utilizó un volumen conocido de buffer (dependiendo del tamaño de la muestra) (0.1 M Tris-HCl pH 8.5, 15\% (p/v) de Polivinil Pirrolidona, $153 \mu \mathrm{M} \mathrm{MgSO}_{4}$ y $0.2 \%$ (p/v) Triton X-100). El volumen de buffer utilizado en la preparación de los homogeneizados varió de acuerdo al tamaño de la larva, de 1 a $5 \mathrm{~mL}$ por larva. Los homogeineizados se almacenaron a $-80^{\circ} \mathrm{C}$.

\section{Prueba de TBARS}

Se aplicó la prueba de TBARS (Janssens et al., 2000) con el fin de evaluar la suceptibilidad de los homogeneizados a la oxidación inducida de los lípidos. Para ello, los homogeneizados se centrifugaron y a $500 \mu \mathrm{L}$ de sobrenadante se agregaron $400 \mu \mathrm{L}$ de ácido tricloroacético al 15\% (TCA) y $800 \mu \mathrm{L}$ de ácido tiobarbitúrico (TBA) (0.67\% diluido en una solución de $\mathrm{NaOH} 0.3 \mathrm{~N})$. Después de calentar $\left(95^{\circ} \mathrm{C}\right)$ por 20 min y enfriar, se indujo la extracción del pigmento agregando $3 \mathrm{~mL}$ de butanol y centrifugando (2000 rpm, $4^{\circ} \mathrm{C}, 5 \mathrm{~min}$ ). Los sobrenadantes se recuperaron y analizaron en un espectrofotómetro de fluoresencia (Spectramax 190, Molecular Devices, Sunnyvale CA 94089, EUA) (Em 555 y Ex 515). Los niveles de TBARS se calcularon con relación a una curva estándar elaborada con dimetilacetato de maldonaldehido (MDA) Los resultados se expresan como moles de MDA mg ${ }^{-1}$ proteína. Las mediciones de proteínas se realizaron aplicando la metodología propuesta por Lowry et al. (1951), usando albúmina como estándar.

\section{Análisis bioquímicos}

Las determinaciones de carbohidratos y proteínas se realizaron siguiendo las metodologías de Holland y Gabbot (1971) y Bradford (1976). Para ello, se centrifugaron $200 \mu \mathrm{L}$ de homogeneizados previamente mezclados con $15 \%$ de ácido tricloroacético (TCA). Los pelets se lavaron con TCA al 5\% y las dos fracciones sobrenadantes se combinaron. Las fracciones sobrenadantes se usaron para las determinaciones de carbohidratos, mientras que los pelets se utilizaron para las mediciones de proteínas. A las fraciones sobrenadantes $(50 \mu \mathrm{L})$ se les agregó $50 \mu \mathrm{L}$ de fenol al $5 \%$ y $200 \mu \mathrm{L}$ de $\mathrm{H}_{2} \mathrm{SO}_{4}$ concentrado, y se dejaron incubar durante 30 min a temperatura ambiente. Se midieron las absorbancias a $492 \mathrm{~nm}$ usando glucosa como estándar. Los pelets remanentes se diluyeron en $500 \mu \mathrm{L}$ de $\mathrm{NaOH} 1.0 \mathrm{~N}$, se incubaron a $60^{\circ} \mathrm{C}$ durante 30 min y se neutralizaron con $300 \mu \mathrm{L}$ de $\mathrm{HCl} 1.67 \mathrm{M}$. Los contenidos totales de 
pellet fractions were used for protein measurements. Fifty $\mu \mathrm{L}$ of phenol (5\%) and $200 \mu \mathrm{L}$ of concentrated $\mathrm{H}_{2} \mathrm{SO}_{4}$ were added to the supernatant fractions $(50 \mu \mathrm{L})$. After 30 min incubation (room temperature) the absorbances were measured at $492 \mathrm{~nm}$ using glucose as standard. The remaining pellets were diluted in $500 \mu \mathrm{L}$ of $\mathrm{NaOH} 1.0 \mathrm{~N}$, incubated at $60^{\circ} \mathrm{C}$ for $30 \mathrm{~min}$ and neutralized with $300 \mu \mathrm{L}$ of $\mathrm{HCl} 1.67 \mathrm{M}$. Total protein content was determined using Bradford's reagent (Bradford, 1976). The absorbance was measured at $590 \mathrm{~nm}$ using bovine serum albumin as standard.

Total lipids were extracted according to Bligh and Dyer (1959). Chloroform (500 $\mu \mathrm{L})$ and methanol $(500 \mu \mathrm{L})$ (spectophometric grade) and $400 \mu \mathrm{L}$ distillate water were added to the homogenates $(100 \mu \mathrm{L})$. After centrifugation, the top phase was separated $(100 \mu \mathrm{L})$ and $500 \mu \mathrm{L}$ of $\mathrm{H}_{2} \mathrm{SO}_{4}$ were added to the extract and charred $15 \mathrm{~min}$ at $200^{\circ} \mathrm{C}$. The remaining fractions were diluted in $1 \mathrm{~mL}$ distillate water and from these dilutions, $250 \mu \mathrm{L}$ were used for total lipid content spectrophotometrical determination, at $370 \mathrm{~nm}$ of absorbance using tripalmitin (Glyceryl Tripalmitate, Sigma) as standard.

The energy value of the macronutrients was calculated from the contents of the different biochemical fractions and transformed into energetic equivalents using the enthalpy combustion constants (17500 J g ${ }^{-1}$ carbohydrates, $24000 \mathrm{~J} \mathrm{~g} \mathrm{~g}^{-1}$ protein and $39500 \mathrm{~J} \mathrm{~g}^{-1}$ lipids) (De Coen et al., 1995). Given the small size of the fish, the energetic values were calculated per fish.

\section{Statistical analyses}

Statistical analyses were performed using one-way analysis of variance (ANOVA) and when differences were found, Tukey's honest significant differences test (HSD) was used. The homogeneity of the variances of means was checked by Cochran's univariate test. The level of confidence considered for all the statistical analysis was $a=0.05$.

\section{Results}

\section{Growth, condition and oxidative status}

The biochemical composition of the three diets tested (ash, moisture, protein and lipids), as well as the HUFA fractions in $\mathrm{ME}$ and $\mathrm{MB}$ are shown in table 1 . The cumulative mortality results at two weaning ages (50 and $64 \mathrm{DAH}$ ) showed significantly higher values for late weaning in the Artemia treatment (39\% for the whole experimental period). The other treatments (including frozen Artemia at early weaning) had similar values (around 20-24\%) (fig. 1a, b). No significant differences were observed in the cumulative mortality of the MB and ME diets.

For all the experimental period, the dry weight and standard length results showed similar tendencies for the same treatments regardless of weaning age (tables 2-5). From the beginning of the experiment until days 71 and 78, the dry weight and standard length values were not significantly proteínas se determinaron usando el reactivo de Bradford (Bradford, 1976). Las absorbancias se midieron a $590 \mathrm{~nm}$ usando como estándar albúmina bóvina.

Los lípidos totales se extrajeron de acuerdo con Bligh y Dyer (1959). A $100 \mu \mathrm{L}$ de homogeneizados se adicionaron cloroformo $(500 \mu \mathrm{L})$ y metanol $(500 \mu \mathrm{L})$ (grado espectofotométrico) y $400 \mu \mathrm{L}$ de agua destilada. Después del centrifugado se separó la fase superior $(100 \mu \mathrm{L})$ y se le adicionaron $500 \mu \mathrm{L}$ de $\mathrm{H}_{2} \mathrm{SO}_{4}$; las mezclas se quemaron durante $15 \mathrm{~min}$ a $200^{\circ} \mathrm{C}$. Las fraciones restantes se diluyeron con $1 \mathrm{~mL}$ de agua destilada. A partir de dichas diluciones se tomaron $250 \mu \mathrm{L}$ para la determinación espectrofotométrica del contenido total de lípidos, los cuales se midieron a $370 \mathrm{~nm}$ de absorbancia usando tripalmitina (Gliceril tripalmitato, Sigma) como estándar.

Los valores energéticos de los macronutrientes se calcularon utilizando los contenidos de las diferentes fracciones bioquímicas, los cuales se transformaron en equivalentes energéticos usando las constantes de entalpía de la combustión (17500 J g-1 carbohidratos, $24000 \mathrm{~J} \mathrm{~g}^{-1}$ proteínas y $39500 \mathrm{~J} \mathrm{~g}^{-1}$ lípidos) (De Coen et al., 1995). Debido al tamaño pequeño de los peces, los valores energéticos se calcularon por pez.

\section{Análisis estadístico}

Para el análisis estadístico de los datos se utilizó el análisis de varianza de una vía (ANOVA) y cuando se encontraron diferencias significativas se aplicó la prueba de honestidad de varianza de Tukey (HSD). Se verificó la homogeneidad de varianza de las medias con la prueba univariada de Cochran. El nivel de confianza considerado para todos los análisis fue $a=0.05$.

\section{Resultados}

\section{Crecimiento, condición y estado de oxidación}

En la tabla 1 se presentan la composición bioquímica de las tres dietas probadas (ceniza, humedad, proteínas y lípidos) y las fracciones de HUFA en las dietas inertes. Los resultados de mortalidad acumulada para las dos edades de inicio del destete (50 y $64 \mathrm{DAH}$ ) muestran valores significativamente más altos para el tratamiento con Artemia en el destete tardío (39\% para todo el periodo experimental). Los otros tratamientos (incluyendo el que incluyó Artemia congelada en el destete temprano) tuvieron valores similares, entre $20-24 \%$ (fig. 1a, b). La mortalidad acumulada en las dietas inertes no presentó diferencias significativas.

Para todo el periodo experimental, los resultados de peso seco y longitud estándar presentaron tendencias similares independientemente de la edad de destete (tablas 2-5). Desde el inicio del experimento hasta los días 71 y 78, los valores de peso seco y longitud estándar no presentaron diferencias significativas entre tratamientos. Sin embargo, en las siguientes semanas el crecimiento (peso seco y longitud estándar) fue 

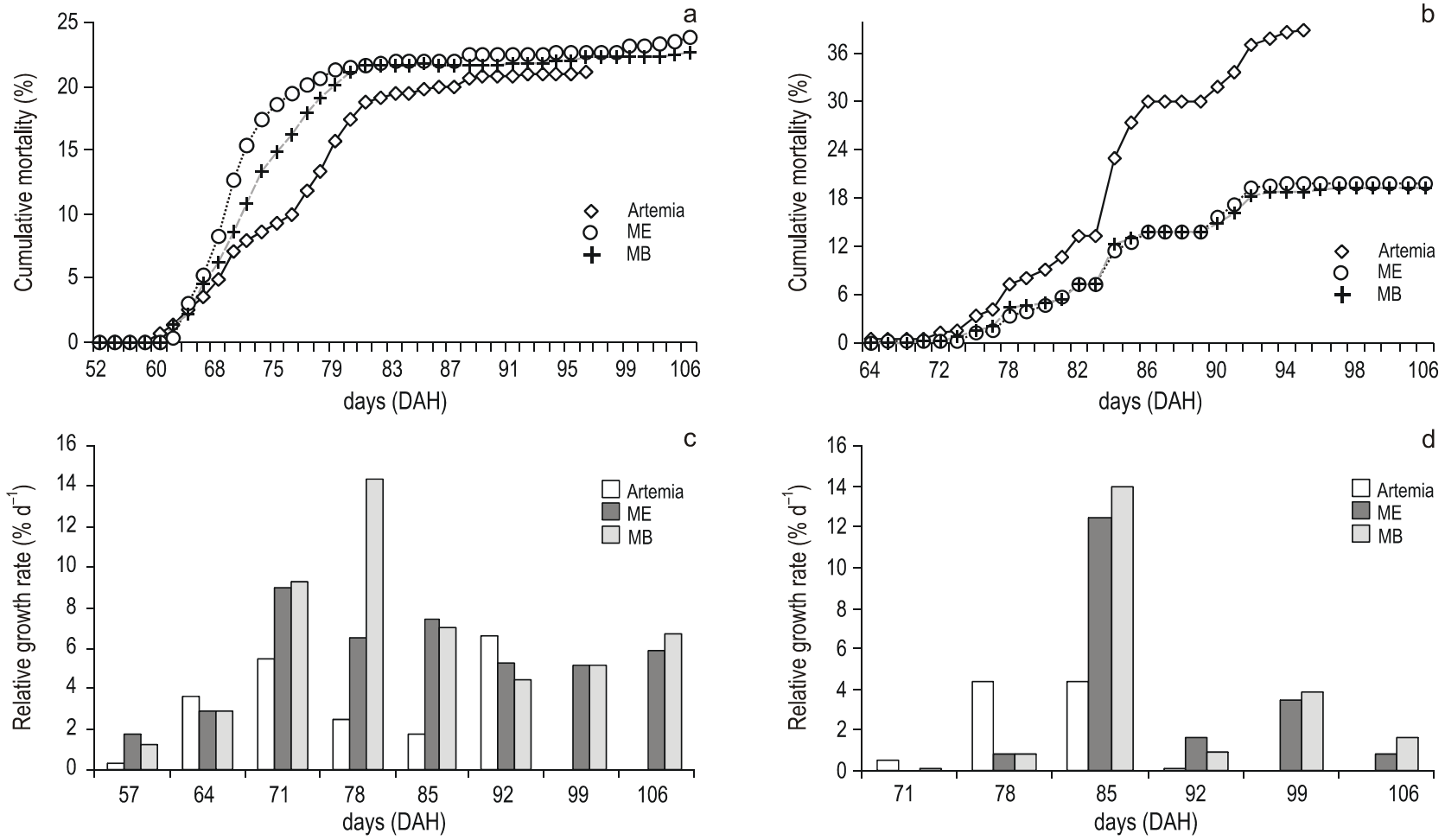

Figure 1. Cumulative mortality at early (a) and late (b) weaning of Solea solea treated with frozen Artemia, micro-extruded (ME) and microbound (MB) diets. Relative growth rate (RGR, $\% \mathrm{~d}^{-1}$ ) for early (c) and late (d) weaning. $n=10$ fish per treatment in each sampling.

Figura 1. Mortandad acumulada en el destete temprano (a) y tardío (b) de Solea solea utilizando dietas de Artemia congelada, microcompactada y micro-extruida. Tasa de crecimiento relativo $\left(\mathrm{RGR}, \% \mathrm{~d}^{-1}\right)$ para el destete temprano (c) y tardío (d). $n=10$ individuos por tratamiento en cada muestreo.

Table 2. Dry weight $(\mathrm{mg})$ of Solea solea at early weaning. Fish treated with frozen Artemia, micro-extruded (ME) and micro-bound (MB) diets.

Tabla 2. Peso seco $(\mathrm{mg})$ de Solea solea al destete temprano. Individuos alimentados con Artemia congelada y las dietas inertes micro-extruida (ME) y micro-compactada (MB).

\begin{tabular}{cccc}
\hline Day & Artemia & ME & MB \\
\hline 50 & $8.0 \pm 0.3$ & $6.8 \pm 0.3$ & $6.6 \pm 0.4$ \\
57 & $8.2 \pm 0.8$ & $7.7 \pm 1.1$ & $7.2 \pm 0.9$ \\
64 & $10.5 \pm 1.0$ & $9.4 \pm 1.1$ & $8.8 \pm 0.3$ \\
71 & $15.2 \pm 1.2$ & $17.2 \pm 1.9$ & $16.4 \pm 2.2$ \\
78 & $18.1 \pm 0.4^{\mathrm{c}}$ & $26.8 \pm 3.1^{\mathrm{b}}$ & $42.0 \pm 8.9^{\mathrm{a}}$ \\
85 & $20.4 \pm 0.8^{\mathrm{c}}$ & $44.2 \pm 3.5^{\mathrm{b}}$ & $67.4 \pm 5.5^{\mathrm{a}}$ \\
92 & $34.2 \pm 2.9^{\mathrm{c}}$ & $63.5 \pm 7.2^{\mathrm{b}}$ & $91.3 \pm 9.1^{\mathrm{a}}$ \\
99 & $*$ & $90.2 \pm 6.9^{\mathrm{b}}$ & $144.0 \pm 6.2^{\mathrm{a}}$ \\
106 & $*$ & $134.8 \pm 6.8^{\mathrm{b}}$ & $205.4 \pm 5.1^{\mathrm{a}}$ \\
\hline
\end{tabular}

Within rows, superscript letters indicate significant differences; $n=10$ fish per treatment. * Not measured.

different between treatments; however, in the following weeks, fish growth (dry weight and standard length) was significantly
Table 3. Dry weight $(\mathrm{mg})$ of Solea solea at late weaning. Fish treated with frozen Artemia, micro-extruded (ME) and micro-bound (MB) diets.

Tabla 3. Peso seco $(\mathrm{mg})$ de Solea solea al destete tardío. Individuos alimentados con Artemia congelada y las dietas inertes micro-extruida (ME) y micro-compactada (MB)

\begin{tabular}{rccc}
\hline Day & Artemia & ME & MB \\
\hline 64 & $9.8 \pm 2.7$ & $10.5 \pm 1.0$ & $9.4 \pm 1.1$ \\
71 & $20.4 \pm 0.7$ & $18.8 \pm 2.5$ & $22.4 \pm 1.9$ \\
78 & $20.5 \pm 1.5$ & $15.8 \pm 0.3$ & $21.0 \pm 0.8$ \\
85 & $15.4 \pm 1.4^{\mathrm{c}}$ & $17.8 \pm 0.6^{\mathrm{b}}$ & $30.6 \pm 1.0^{\mathrm{a}}$ \\
92 & $32.6 \pm 3.6^{\mathrm{c}}$ & $43.5 \pm 2.4^{\mathrm{b}}$ & $49.7 \pm 3.1^{\mathrm{a}}$ \\
99 & $41.5 \pm 2.9^{\mathrm{c}}$ & $66.4 \pm 5.6^{\mathrm{b}}$ & $101.6 \pm 4.9^{\mathrm{a}}$ \\
106 & $*$ & $142.1 \pm 4.6^{\mathrm{b}}$ & $240.2 \pm 5.9^{\mathrm{a}}$ \\
\hline
\end{tabular}

Within rows, superscript letters indicate significant differences; $n=10$ fish per treatment. * Not measured.

significativamente más bajo en el tratamiento con Artemia, comparado con los peces alimentados con las dietas inertes $(P<0.05)$ (tablas $2-5)$. Después del día $85(\mathrm{DAH})$, los peces alimentados con MB presentaron un crecimiento 
Table 4. Standard length $(\bar{X} \pm S D$; mm) of Solea solea at early weaning. Fish treated with frozen Artemia, micro-extruded (ME) and micro-bound (MB) diets.

Tabla 4. Longitud estándar $(\bar{X} \pm D E ; \mathrm{mm})$ de Solea solea al destete temprano. Individuos alimentados con Artemia congelada y las dietas inertes micro-extruida (ME) y micro-compactada (MB).

\begin{tabular}{cccc}
\hline Day & Artemia & ME & MB \\
\hline 50 & $88.7 \pm 10.2$ & $84.4 \pm 9.6$ & $84.5 \pm 8.1$ \\
57 & $93.0 \pm 7.3$ & $90.7 \pm 8.8$ & $100.0 \pm 7.3$ \\
64 & $119.1 \pm 13.5$ & $106.7 \pm 18.7$ & $91.8 \pm 14.2$ \\
71 & $110.1 \pm 12.8$ & $103.8 \pm 12.1$ & $109.5 \pm 16.4$ \\
78 & $119.3 \pm 13.1$ & $115.2 \pm 13.1$ & $114.7 \pm 8.1$ \\
85 & $139.7 \pm 37.0^{\mathrm{c}}$ & $219.3 \pm 55.7^{\mathrm{b}}$ & $292.1 \pm 50.7^{\mathrm{a}}$ \\
92 & $234.0 \pm 38.0^{\mathrm{c}}$ & $303.0 \pm 44.0^{\mathrm{b}}$ & $357.0 \pm 25.0^{\mathrm{a}}$ \\
99 & $*$ & $347.0 \pm 30.0^{\mathrm{b}}$ & $399.0 \pm 25.0^{\mathrm{a}}$ \\
106 & $*$ & $402.0 \pm 42.0_{\mathrm{b}}$ & $487.0 \pm 34.0^{\mathrm{a}}$ \\
\hline
\end{tabular}

Within rows, superscript letters indicate significant differences;

$n=10$ fish per treatment. * Not measured.

lower in the Artemia treatment when compared with the inert diets $(P<0.05)$ (tables $2-5)$. After $85 \mathrm{DAH}$, the fish fed the MB diet displayed a significantly greater growth (dry weight and standard length) performance, followed by ME and finally Artemia for both weaning ages, except for the standard length measures on day 92 for both weaning ages. At this moment no significant differences were observed between the two inert diets (tables 4, 5). At the end of the experimental period (106 DAH) (the data were analyzed as point values), no significant differences in growth (dry weight and standard length) were detected between fish treated with the same diet at different weaning ages $(P<0.05)$. Because of the high mortality and the low dry weight and standard length increases obtained, the Artemia-fed group was stopped 92 and 99 DAH for early and late weaning, respectively.

The relative growth rate (RGR) showed significant differences among the diets. Fish fed Artemia reached a significantly higher RGR in the second week and in the first two weeks on early and late weaning, respectively; however, in subsequent weeks the RGR decreased to almost imperceptible, except for early weaning on day 92. In the case of early weaning, from day 71 to the end of the experiment, the highest weekly RGR alternated between MB and ME without a clear tendency. For late weaning, fish treated with the MB diet showed better performance in terms of RGR (fig. 1c, d). No significant differences were found for the condition factor between the two weaning ages $(P<0.05)$ (table 6$)$; however, higher condition factor values was observed for early weaning. There were no significant differences in the results of the susceptibility to oxidation test (TBARS) between treatments $(P<0.05)$ (table 6).
Table 5. Standard length $(\bar{X} \pm S D ; \mathrm{mm})$ of Solea solea at late weaning. Fish treated with frozen Artemia, micro-extruded (ME) and micro-bound (MB) diets.

Tabla 5. Longitud estándar ( $\bar{X} \pm D E$;mm) de Solea solea al destete tardío. Individuos alimentados con Artemia congelada y las dietas inertes micro-extruida (ME) y micro-compactada (MB).

\begin{tabular}{cccl}
\hline Day & Artemia & ME & \multicolumn{1}{c}{ MB } \\
\hline 64 & $116.1 \pm 8.3$ & $110.3 \pm 12.5$ & $116.4 \pm 9.8$ \\
71 & $120.1 \pm 9.8$ & $114.0 \pm 10.5$ & $123.8 \pm 16.4$ \\
78 & $161.8 \pm 30.2$ & $108.0 \pm 12.1$ & $117.3 \pm 13$ \\
85 & $218.5 \pm 21.7^{\mathrm{c}}$ & $259.6 \pm 35.7^{\mathrm{b}}$ & $308.7 \pm 31.8^{\mathrm{a}}$ \\
92 & $220.0 \pm 33.0^{\mathrm{c}}$ & $290.0 \pm 40.0^{\mathrm{b}}$ & $330.1 \pm 29.0^{\mathrm{a}}$ \\
99 & $*$ & $369.0 \pm 24.6^{\mathrm{b}}$ & $430.1 \pm 29.5^{\mathrm{a}}$ \\
106 & $*$ & $390.0 \pm 30.0^{\mathrm{b}}$ & $480.0 \pm 30.0^{\mathrm{a}}$ \\
\hline
\end{tabular}

Within rows, superscript letters indicate significant differences; $n=10$ fish per treatment. ${ }^{*}$ Not measured.

significativamente mayor (peso seco y longitud estándar), seguidos por los alimentados con ME, y finalmente los alimentados con Artemia para ambas edades de destete. Sin embargo, en el día 92 se observó una excepción en los valores de longitud estándar en las dos edades de destete. En este momento no se registraron diferencias significativas entre los dos alimentos inertes (tablas 4, 5). Al final del periodo experimental (106 DHA) (los datos se analizaron como valores puntuales) no se detectaron diferencias significativas en el crecimiento en peso seco y longitud estándar entre los peces tratados con la misma dieta aunque destetados a diferentes edades $(P<0.05)$. Debido a los pobres resultados obtenidos en términos de mortalidad, peso seco y longitud estándar, el grupo alimentado con Artemia se excluyó del experimento al día 92 y 99 DAH para el destete temprano y tardío, respectivamente.

La tasa de crecimiento relativo (RGR) presentó diferencias significativas entre las dietas. Los peces alimentados con Artemia alcanzaron valores significativamente más altos de RGR en la segunda y en las primeras dos semanas de experimentación para el destete temprano y tardío, respectivamente. Sin embargo, en las semanas siguientes la RGR disminuyó hasta casi ser imperceptible excepto para el día 92 con destete temprano. En el caso del destete temprano, a partir del día 71 y hasta el final del experimento, los valores semanales más altos de RGR se alternaron entre MB y ME sin una tendencia clara. En el caso del destete tardío, los peces alimentados con MB presentaron una tendencia a un mejor crecimiento en términos de RGR (fig. 1c, d). El factor de condición no mostró diferencias significativas entre las dos edades de destete $(P<0.05)$ (tabla 6). No obstante, se observó una tendencia a mayores valores de factor de condición en el destete temprano. Los resultados de la prueba de TBARS no evidenciaron diferencias significativas entre tratamientos $(P<0.05)$ (tabla 6$)$. 
Table 6. Condition factor (CF) and thiobarbituric acid reactive substances (TBARS) in whole-body homogenates of Solea solea at the end of the experiment (106 days after hatching). Fish weaned with frozen Artemia, micro-extruded (ME) and micro-bound (MB) diets, at early (EW) and late (LW) weaning. Tabla 6. Factor de condición (CF) y prueba de sustancias reactivas al ácido tiobarbitúrico (TBARS) para homogeneizados de Solea solea completos al final del experimento (106 días después de la eclosión). Peces alimentados con dietas de Artemia congelada, mico-extruida (ME) y micro-compactada (MB), al destete temprano $(\mathrm{EW})$ y tardío (LW).

\begin{tabular}{cccccc}
\hline \multirow{2}{*}{ Treatment } & \multicolumn{2}{c}{ CF } & & \multicolumn{2}{c}{ TBARS } \\
\cline { 2 - 3 } \cline { 5 - 6 } & EW & LW & & EW & LW \\
\hline Artemia & $0.86 \pm 0.21$ & $0.45 \pm 0.11$ & & \\
ME & $0.81 \pm 0.17$ & $0.55 \pm 0.13$ & & $4.00 \mathrm{E}-08 \pm 1.60 \mathrm{E}-09$ & $3.10 \mathrm{E}-08 \pm 6.90 \mathrm{E}-09$ \\
MB & $0.87 \pm 0.24$ & $0.50 \pm 0.12$ & & $3.60 \mathrm{E}-08 \pm 8.80 \mathrm{E}-09$ & $3.50 \mathrm{E}-08 \pm 9.70 \mathrm{E}-09$ \\
\hline
\end{tabular}

TBARS activity results are expressed as $\mathrm{mol} \mathrm{mg}^{-1}$ protein; $n=12$ fish per treatment at each weaning time.

$\mathrm{CF}$ : (dry weight/standard length $\left.{ }^{3}\right) \times 100$. CF results are in $\mathrm{g} / \mathrm{mm}^{3}$. Results presented as means \pm standard deviation.

Table 7. Energetic contents for different macronutrient fractions (mean \pm standard deviation) in whole-body homogenates of Solea solea at early weaning (DAH = days after hatching). Fish treated with frozen Artemia, micro-extruded (ME) and micro-bound (MB) diets.

Tabla 7. Contenidos energéticos para las diferentes fracciones de macronutrientes (media \pm desviación estándar) en homogeneizados de Solea solea completos al destete temprano (DAH = días después de la eclosión). Peces tratados con dietas de Artemia congelada, micro-extruida (ME) y micro-compactada (MB).

\begin{tabular}{lccc}
\hline Time & \multicolumn{3}{c}{ Dietary treatments } \\
\cline { 2 - 4 } & $\begin{array}{c}\text { Frozen Artemia } \\
\left(\mathrm{J} \mathrm{fish}^{-1}\right)\end{array}$ & $\begin{array}{c}\mathrm{ME} \\
\left(\mathrm{J} \mathrm{fish}^{-1}\right)\end{array}$ & $\begin{array}{c}\mathrm{MB} \\
\left(\mathrm{J} \mathrm{fish}^{-1}\right)\end{array}$ \\
\hline $\mathbf{5 0}$ DAH & & & \\
Carbohydrates & $30.7 \pm 0.0$ & $30.7 \pm 0.0$ & $30.7 \pm 0.0$ \\
Proteins & $1121.9 \pm 7.9$ & $1121.9 \pm 7.9$ & $1121.9 \pm 7.9$ \\
Lipids & $4009.0 \pm 11.4$ & $4009.0 \pm 11.4$ & $4009.0 \pm 11.4$
\end{tabular}

\title{
64 DAH
}

Carbohydrates

Proteins

Lipids

\section{DAH}

Carbohydrates

Proteins

Lipids

\section{DAH}

Carbohydrates

Proteins

Lipids

$32.5 \pm 1.1^{\mathrm{a}}$
$3626.6 \pm 155.4$
$5499.0 \pm 282.1^{\mathrm{a}}$

$65.1 \pm 0.3^{\mathrm{a}}$

$6077.1 \pm 18.0^{\mathrm{a}}$

$11607.8 \pm 282.1^{\mathrm{a}}$
$65.2 \pm 0.2^{\mathrm{a}}$

$6105.6 \pm 16.5^{\mathrm{b}}$

$11995.2 \pm 201.1^{\mathrm{a}}$
$30.5 \pm 0.1^{\mathrm{b}}$

$3645.7 \pm 136.4$

$4661.9 \pm 196.5^{b}$

$3650.6 \pm 107.9$

$3873.3 \pm 203.7^{c}$

\author{
$64.1 \pm 0.3^{\mathrm{b}}$ \\ (2) \\ $11380.2 \pm 302.9^{b}$
}

\section{DAH}

Carbohydrates

Proteins

Lipids

$85.5 \pm 0.4^{\mathrm{b}}$
$16304.7 \pm 393.3^{\mathrm{a}}$
$21863.1 \pm 161.8^{\mathrm{b}}$

$149.8 \pm 0.9$

$15193.1 \pm 36.7^{\mathrm{a}}$

$32820.5 \pm 1869.8$
$84.74 \pm 0.8^{\mathrm{c}}$

$15882.5 \pm 270.0^{\mathrm{b}}$

$22377.0 \pm 200.8^{\mathrm{a}}$

Within rows, superscript letters indicate significant differences $(P<0.05) ; n=12$ fish per treatment at each sampling. 


\section{Biochemical contents}

The macromolecule contents (carbohydrates, proteins and lipids) determined every 14 days for early and late weaning are presented in tables 7 and 8. In the first early weaning sampling on day 64 (table 7), carbohydrates and lipids were significantly higher in fish fed frozen Artemia $(P<0.05)$, but on day 78 they presented similar values in the MB and Artemia diets. On day 92, lipids were higher in fish fed the MB diet, but carbohydrates were significantly higher in fish fed Artemia, while proteins were significantly higher in the Artemia and ME treatments. For early weaning on day 106, no significant differences were found between the two inert diets, except for the protein contents (table 7).

\section{Contenidos bioquímicos}

En las tablas 7 y 8 se presentan los resultados de los contenidos de las macromoléculas (carbohidratos, proteínas y lípidos) determinados cada 14 días en los casos de destete temprano y tardío. Durante el primer muestreo del destete temprano (64 DAH) (tabla 7) los carbohidratos y lípidos fueron significativamente más altos en los peces alimentados con Artemia congelada $(P<0.05)$. Sin embargo, al día 78 (DAH) se midieron valores similares de los contenidos bioquímicos tanto en el tratamiento con $\mathrm{MB}$ como en el tratamiento con Artemia. En el día 92 (DAH) se registraron valores superiores de lípidos en los tejidos de los peces alimentados con $\mathrm{MB}$, en tanto que los carbohidratos fueron significativamente más altos con el tratamiento de Artemia y los contenidos de proteínas

Table 7. Energetic contents (one-time point values) for different macronutrient fractions (mean \pm standard deviation) in whole-body homogenates of Solea solea at early weaning (DAH = days after hatching). Fish treated with frozen Artemia, micro-extruded (ME) and micro-bound (MB) diets.

Tabla 7. Contenidos energéticos (valores medidos puntualmente) para las diferentes fracciones de macronutrientes (media \pm desviación estándar) en homogeneizados de Solea solea completos al destete temprano (DAH = días después de la eclosión). Peces tratados con dietas de Artemia congelada, micro-extruida (ME) y micro-compactada (MB).

\begin{tabular}{lccc}
\hline Time & \multicolumn{3}{c}{ Dietary treatments } \\
\cline { 2 - 4 } & $\begin{array}{c}\text { Frozen Artemia } \\
\left(\mathrm{J} \mathrm{fish}^{-1}\right)\end{array}$ & $\begin{array}{c}\mathrm{ME} \\
\left(\mathrm{J} \mathrm{fish}^{-1}\right)\end{array}$ & $\begin{array}{c}\mathrm{MB} \\
\left(\mathrm{J} \mathrm{fish}^{-1}\right)\end{array}$ \\
\hline $\mathbf{5 0}$ DAH & & & \\
Carbohydrates & $30.7 \pm 0.0$ & $30.7 \pm 0.0$ & $30.7 \pm 0.0$ \\
Proteins & $1121.9 \pm 7.9$ & $1121.9 \pm 7.9$ & $1121.9 \pm 7.9$ \\
Lipids & $4009.0 \pm 11.4$ & $4009.0 \pm 11.4$ & $4009.0 \pm 11.4$
\end{tabular}

\section{DAH}

Carbohydrates

Proteins

Lipids

\section{DAH}

Carbohydrates

Proteins

Lipids

\section{DAH}

Carbohydrates

Proteins

Lipids

$$
\begin{gathered}
86.7 \pm 0.1^{\mathrm{a}} \\
16513.0 \pm 137.2^{\mathrm{a}} \\
20506.1 \pm v 522.3^{\mathrm{c}}
\end{gathered}
$$

$30.4 \pm 0.1^{\mathrm{b}}$
$3650.6 \pm 107.9$
$3873.3 \pm 203.7^{\mathrm{c}}$

$30.5 \pm 0.1^{\mathrm{b}}$

$3645.7 \pm 136.4$

$4661.9 \pm 196.5^{b}$

\section{DAH}

Carbohydrates

Proteins

Lipids

$\begin{array}{rlrl}65.1 & \pm 0.3^{\mathrm{a}} & 64.1 & \pm 0.3^{\mathrm{b}} \\ 6077.1 & \pm 18.0^{\mathrm{a}} & 6095.8 & \pm 9.8^{\mathrm{a}} \\ 11607.8 & \pm 282.1^{\mathrm{a}} & 11380.2 \pm 302.9^{\mathrm{b}}\end{array}$

$85.5 \pm 0.4^{\mathrm{b}}$

$16304.7 \pm 393.3^{\mathrm{a}}$

$21863.1 \pm 161.8^{\mathrm{b}}$
$84.74 \pm 0.8^{c}$

$15882.5 \pm 270.0^{\mathrm{b}}$

$22377.0 \pm 200.8^{\mathrm{a}}$

Within rows, superscript letters indicate significant differences $(P<0.05) ; n=12$ fish per treatment at each sampling. 
In the case of late weaning, higher values were observed in nearly all the biochemical compounds was evident for MB. However, in fish fed with inert diets, significantly higher lipid contents were recorded on days 78 and 92, and on day 106 they were significantly higher for MB (table 8).

\section{Discussion}

The mortality rates observed during the present experiment (20-24\% and 39\% for Artemia early weaning) were lower than the values found by Gatesoupe and Luquet (1981), who weaned sole larvae $70 \mathrm{DAH}$, obtaining mortalities of $55-70 \%$. These authors obtained a lower mortality (20.5\%) when Dover sole larvae were reared using frozen Artemia nauplii from 10 to $15 \mathrm{DAH}$.

Metailler et al. (1981) reported a survival rate of 30-40\% for fish weaned with different diets (mixed dry pellets and fresh ingredients as attractants), compared with the 100\% obtained for larvae fed with live Artemia. The same authors found that dry pellets induced greater growth of sole larvae (90 DAH), comparable with that obtained feeding with live Artemia. In the present experiment, frozen Artemia was well accepted by the fish only the first $30 \mathrm{~min}$ after the addition, and the remaining fraction was ignored (producing deterioration of water quality until it was siphoned out from the tank). The lowest mortality rates of the present study were also comparable to the best results obtained by Day et al. (1997), although this latter study was performed with sole over $170 \mathrm{DAH}$.

Metailler et al. (1981) reported the highest weight (751 \pm $102 \mathrm{mg}$ ) of Dover sole cultured until $90 \mathrm{DAH}$, when fish were fed with dry pellets, but with a low survival of $38 \%$. This result was lower when compared with our results $(76-80 \%$ of survival with inert diets and $61 \%$ for the Artemia early weaning treatment). The average length (32 $\mathrm{mm}$ after 60 days of culture) recorded in Dendrinos and Thorpe's (1987) experiment, was lower compared with the results of the present work. During the first three weeks of the experiment, dry weight and standard length did not increase markedly and this could be considered a long adaptation period to the new food; however, after this period the growth pattern changed radically for all treatments, particularly for Artemia. During the first two weeks of the experiment, the results obtained in the frozen Artemia treatment were satisfactory in terms of dry weight, standard length and biochemical composition (tables 2, 3, 4, 5, 7, 8).

Gatesoupe and Luquet (1981) and Fuchs (1982) successfully weaned S. solea using frozen Artemia nauplii. Nevertheless, for the later stages of cultivation, as opposed to the inert diets, frozen Artemia does not seem to meet the nutritional requirements of sole (tables 7, 8). Person-LeRuyet et al. (1990) recommended the use of frozen adult Artemia to aid the transition of the weaning. The results of dry weight, standard length, condition factor, relative growth rate $57 \mathrm{DAH}$ and biochemical composition at early weaning on day 64 for fish fed frozen Artemia support this suggestion; however, for later stages, frozen Artemia was not an appropriate feed. It should be fueron significativamente más altoss en los tratamientos con Artemia y con ME. Para el día 106 (DAH) en el destete temprano, las dietas inertes no presentaron diferencias significativas entre ellas, excepto para los contenidos proteicos (tabla 7).

En el caso del destete tardío se evidenció una tendencia a valores más altos de todos los componentes bioquímicos en la dieta con MB. Los peces alimentados con las dietas inertes presentaron los niveles de lípidos significativamente más altos en los días 78 y 92 (DAH), y para el día 106 éstos fueron significativemente más altos para la dieta con MB (tabla 8).

\section{Discusión}

Las tasas de mortalidad observadas en este experimento (20-24\%, y 39\% para el tratamiento con Artemia y destete temprano), son menores que los valores encontrados por Gatesoupe y Luquet (1981), quienes destetaron larvas de sol después de $70 \mathrm{DAH})$. Estos autores obtuvieron mortalidades entre 55-70\%; no obstante, sus valores de mortalidad fueron menores (20.5\%) cuando las larvas del sol común se cultivaron usando nauplios de Artemia congelada, a partir de 10 a 15 DAH respectivamente.

Metallier et al. (1981) encontraron que la tasa de supervivencia de los peces destetados con diferentes dietas (pelets secos mezclados con ingredientes frescos como atrayentes) alcanzó de $30 \%$ a $40 \%$, en comparación con el $100 \%$ obtenido en larvas alimentadas con Artemia viva. Los mismos autores observaron que el uso de los pellets secos induce a un mayor crecimiento de las larvas de sol (90 DAH), comparable con el obtenido utilizando Artemia viva como alimento. En el presente experimento los peces aceptaron bien la Artemia congelada sólo durante los primeros 30 min después de su adición, posteriormente ignoraron la fracción remanente (produciendo deterioro en la cálidad del agua hasta que fue sifoneada hacia afuera del tanque). De entre los valores de mortalidad obtenidos en el presente estudio, los más bajos son comparables con los mejores resultados de Day et al. (1997), aunque este último estudio se realizó con juveniles del sol común de 170 DHA.

Metailler et al. (1981) alimentaron larvas de sol (90 DAH) con pelets secos obteniendo peso mayor (751 $\pm 102 \mathrm{mg}$ ) pero también una baja supervivencia (38\%). Estos resultados fueron menores a los obtenidos en el presente trabajo (76-80\% de supervivencia con dietas inertes y $61 \%$ para el tratamiento con Artemia y destete temprano). La longitud media (32 mm después de 60 días de cultivo) registrada en el experimento de Dendrinos y Thorpe (1987) fue menor que el promedio de las longitudes alcanzadas en el presente trabajo. Durante las primeras tres semanas de experimentación, el peso seco y la longitud estándar no incrementaron marcadamente, lo cual puede ser considerado como un periodo largo de adaptación al nuevo alimento. Sin embargo, después de este periodo el patrón de crecimiento cambió radicalmente para todos los tratamientos, especialmente para los peces alimentados con Artemia 
considered that weaning success depends not only on the quality of the diet, but also on the physiological state, developmental stage and age of the larvae. Furthermore, the present results suggest that the first four weeks of weaning are a critical period, with a tendency towards growth diminution and depletion of the energy reserves. A depletion of the lipid stores seems particularly important when fish are weaned early (table 7).

Alvarez et al. $(1998,1999)$ suggested that diets should be evaluated in terms of fatty acid composition and the susceptibility to oxidation of the fish tissue. Lipid in the diet is also considered to be important in the lipid oxidation process in muscle homogenates of rainbow trout and European seabass (López-Bote et al., 2001). In this case, the similar amounts of HUFA in the inert diets were reflected in the absence of significant differences in the levels of TBARS.

The effect of diets on larvae has commonly been evaluated based on growth, survival and condition factor, but these parameters cannot offer a full image of the physiological condition. The acute salinity stress test proposed by Dhert et al. (1992) was applied in order to expose the fish to extreme conditions and to test their resistance capacity (results not presented). Sole larvae showed a tolerance to high salinities and no clear effect of the diet was evidenced. Yin and Blaxter (1987) also observed an excellent low salinity tolerance of euryhaline marine fish larvae (flounder), but there are no references dealing with tolerance to high salinities. Future experiments should consider the acute ammonia stress test. Cavalli (2000), Hernández (2001) and Palacios et al. (2002) found that it was a feasible and sensitive criterion for quality determination of crustacean larvae of Macrobrachium rosembergii, Peneaus vannamei and Litopeneaus vannamei.

According to the results found in the present work, early weaning starting on day 50 is suitable for $S$. solea larvae. Of the diets tested, the MB diet proved to be the most appropriate for weaning Dover sole, producing higher survival, growth and energy reserves.

\section{Acknowledgements}

We thank Peter Bossier for critically reviewing the manuscript. Rebeca Rueda and Luis Conceição acknowledge support from CONACYT (Mexico) and grant SFRH/BPD/ 7149/2001 (FCT, Portugal), respectively. The technical assistance of Cecile Marchand and Geert Van De Wielde is greatly appreciated.

\section{References}

Alvarez, M.J., López-Bote, C.J., Diez, A., Corraze, G., Arzel, J., Días, J., Kaushik, S.J. and Bautista, J.M. (1998). Dietary fish oil and digestible protein modify susceptibility to lipid peroxidation in the muscle of rainbow trout (Oncorhynchus mykiss) and sea bass (Dicentrarchus labrax). Brit. J. Nutr., 80: 281-289.

Alvarez, M.J., López-Bote, C.J., Diez, A., Corraze, G., Arzel, J., Días, J., Kaushik, S.J. and Bautista, J.M. (1999). The partial substitution congelada. Durante las primeras dos semanas de experimentación no hubo un marcado aumento ni del peso seco ni de la longitud estándar, lo cual puede ser considerado como un periodo largo de adaptación al nuevo alimento. Sin embargo, después de éste, el patrón de crecimiento cambió radicalmente con todos los tratamientos, especialmente para los peces alimentados con Artemia congelada. Durante las primeras dos semanas de experimentación, los resultados obtenidos con Artemia congelada fueron satisfactorios en términos de peso seco, longitud estándar y composición bioquímica (tablas 2, 3, $4,5,7,8)$.

Gatesoupe y Luquet (1981) y Fuchs (1982) destetaron exitosamente larvas de $S$. solea usando nauplios de Artemia congelada. No obstante, para las etapas posteriores de cultivo y a diferencia de las dietas inertes, Artemia congelada no parece cubrir las necesidades nutricionales del sol (tablas 7, 8). Person-LeRuyet et al. (1990) recomiendan el uso de Artemia congelada para ayudar en la transición del destete. Esta sugerencia está apoyada en los resultados de peso seco, longitud estándar, factor de condición, tasa de crecimiento relativo en el día 57 (DAH) y por la composición bioquímica en el destete temprano para $64 \mathrm{DAH}$. Sin embargo, para etapas posteriores la Artemia congelada no fue un alimento adecuado. Debe considerarse que el éxito del proceso de destete no sólo depende de la calidad de la dieta, sino también del estado fisiológico, del estado de desarrollo y de la edad de la larva. Los resultados del presente estudio sugieren que las primeras cuatro semanas de destete son un periodo crítico, con tendencia a la disminución del crecimiento y el agotamiento de las reservas de energía. El agotamiento de las reservas lipídicas parece ser particularmente importante cuando los peces se destetan temprano (tabla 7).

Álvarez et al. $(1998,1999)$ sugirieron que las dietas deben ser evaluadas en términos de la composición de ácidos grasos y de la suceptibilidad a la oxidación de los tejidos de los peces. López-Bote et al. (2001) observaron que los lípidos en la dieta son también de importancia en el proceso de oxidación de los lípidos en homogeneizados de músculo de la trucha arcoiris y la luvina. En el presente experimento los niveles similares de HUFAs en las dietas inertes se reflejaron en la ausencia de diferencias significativas en los niveles de TBARS.

El efecto de las dietas en las larvas se ha evaluado comúnmente a través de los parámetros crecimiento, supervivencia y factor de condición. Sin embargo, estos parámetros no pueden ofrecer una imagen completa de la condición fisiológica. La prueba de salinidad aguda propuesta por Dhert et al. (1992) se aplicó para someter a los peces a condiciones extremas y así probar su capacidad de resistencia (resultados no presentados). No obstante, las larvas de sol presentaron una elevada tolerancia a altas salinidades por lo que no se detectó un efecto claro de la dieta. Yin y Blaxter (1987) observaron una excelente tolerancia a bajas salinidades en larvas de peces marinos eurihalinos (peces planos), pero no existen referencias respecto a la tolerancia a altas salinidades. En experimentos futuros se debe considerar la prueba de estrés agudo al amonio. Cavalli (2000), 
of digestible protein with gelatinized starch as an energy source reduces susceptibility to lipid oxidation in rainbow trout (Oncorhynchus mykiss) and sea bass (Dicentrarchus labrax) muscle. J. Anim. Sci., 77: 3322-3329.

AOAC (Association of Official Analytical Chemist) (1984). Official Methods of Analysis. 14th ed. AOAC, Arlington, VA, 1141 pp.

Bligh, E.G. and Dyer, W.J. (1959). A rapid method of total lipid extraction and purification. Can. J. Biochem. Physiol., 37: 911917.

Bradford, M. (1976). A rapid and sensitive method for the quantification of microgram quantities of protein utilizing the principle dye binding. Anal. Biochem., 72: 248-254.

Cavalli, R., Menschaert, G., Lavens, P. and Sorgeloos, P. (2000). Maturation performance, offspring quality and lipid composition of Macrobrachium rosenbergii females fed increasing levels of dietary phospholipids. Aquacult. Int., 8: 41-58.

Coutteau, P. and Sorgeloos, P. (1995). Intercalibration exercise on the qualitative and quantitative analysis of fatty acids in Artemia and marine samples. ICES Coop. Res. Rep., 211, 30 pp.

Day, O.J., Howell, B.R. and Jones, D.A. (1997). The effect of dietary hydrolysed fish protein concentrate on the survival and growth of juvenile Dover sole, Solea solea (L.), during and after weaning. Aquacult. Resour., 28: 911-921.

DeCoen, W.M., Janssens, C.R. and Persoone, G. (1995). Biochemical assessment of Cellular Energy Allocation in Daphnia magna exposed to toxic stress as an alternative to the conventional "Scope for Growth" methodology. ANPP Int. Symp. Biological Markers of Pollution. Chinon, France, 21-22 Sept., 1995.

Dendrinos, P. and Thorpe, J.P. (1987). Experiments on the artificial regulation of the amino acid and fatty acid contents of food organisms to meet the assessed nutritional requirements of larval, post-larval and juvenile Dover sole (Solea solea (L.)). Aquaculture, 61: 121-154.

Dhert, P., Lavens, P. and Sorgeloos, P. (1992). Stress evaluation: A tool for quality control of hatchery-produced shrimp and fish fry. Aquacult. Eur., 17(2): 23-125.

Folch, J., Lees, M. and Staley, G.H.S. (1957). A simple method for the isolation and purification of total lipids from animal tissues. J. Biol. Chem., 266: 497-509.

Fuchs, J. (1982). Production de juveniles de sole (Solea solea) en conditions intensives. I. Le premier mois d élevage. Aquaculture, 26: 321-339.

Gatesoupe, F.J. and Luquet, P. (1981). Weaning of the sole (Solea solea) before metamorphosis. Aquaculture, 26: 358-368.

Hernández, R. (2001). Biochemical and physiological indicators of larval and postlarval quality of white shrimp Litopenaeus vannamei (in Spanish). Centro de Investigaciones Biológicas del Noroeste, S.C., México, La Paz, México, 91 pp.

Holland, D. and Gabot, P. (1971). Micro-analytical scheme for determination of proteins, carbohydrate, lipid and RNA levels in marine invertebrate larvae. J. Mar. Biol. Assays UK, 51: 659-668.

Janssens, B.J., Childress, J.J., Baguet, F. and Rees, J.F. (2000). Reduced enzymatic antioxidative defense in deep-sea fish. J. Exp. Biol., 203: 3717-3725.

López-Bote, C.J., Diez, A., Corraze, G., Arzel, J., Alvarez, M.J., Días, J., Kaushik, S.J. and Bautista, J.M. (2001). Dietary protein source affects the susceptibility to lipid peroxidation of rainbow trout (Oncorhynchus mykiss) and sea bass (Dicentrarchus labrax) muscle. Anim. Sci., 73: 443-449.

Lowry, O.H., Rosebrough, N.L. and Randall, R.I. (1951). Protein measurement with Folin phenol reagent. J. Biol. Chem., 193: 265-275.
Hernández (2001) y Palacios et al. (2002) encontraron viable esta prueba y la consideraron un criterio sensible para la determinación de la calidad de las larvas de crustáceos de Macrobrachium rosembergii, Peneaus vannamei y Litopeneaus vannamei.

De acuerdo con los resultados encontrados en el presente trabajo, un destete temprano iniciando en el día 50 es adecuado para las larvas de $S$. solea. De las dietas probadas, la de MB demostró ser la más adecuada para el destete del sol común, produciendo una buena supervivencia, mejor crecimiento y mayores reservas de energías.

\section{Agradecimientos}

Los autores agradecen al profesor Peter Bossier su ayuda en la revisión del manuscrito. Rebeca Rueda y Luis Conceição reconocen y agradecen el apoyo de las becas CONACYT (México) y SFRH/BPD/7149/2001 (FCT, Portugal), respectivamente. Este tabajo no hubiera sido posible sin la asistencia técnica de Cecile Marchand y Geert Van De Wielde.

Traducido al español por los autores.

Metallier, R., Menu, B. and Moriniere, P. (1981). Weaning of Dover sole (Solea vulgaris) using artificial diets. J. World Maricult. Soc., 12(2): 111-116.

Palacios, E., Bonilla, A., Pérez, A. and Racotta, I.S. (2002). Effect of different levels of HUFA on osmoregulatory mechanisms in Penaeus vannamei postlarvae. Abstracts, Annual Meeting of the World Aquaculture Society. China, 23-27 April, 2002.

Person-Le Ruyet, J. (1984). Production of sole and turbot juveniles at IFREMER. Acts of the Norwegian-French Workshop on Aquaculture, pp. 157-177.

Person-LeRuyet, J., Lahayane, J., Deniel, C., Metallier, R., Devauchelle, N., Menu, B., Noel, T. and Baudin-Laurencin, F. (1990). Sole and turbot culture. In: G. Barnabé (ed.), Aquaculture. Vol. 2. Ellis Horwood, London, pp. 687-734.

Tocher, D.R., Mourente, G., Van Der Eecken, A., Evjemo, J.O., Diaz, E., Bell, J.G., Geurden, I. and Olsen, Y. (2002a). Effects of dietary vitamin $\mathrm{E}$ on antioxidant defence mechanisms of juvenile turbot (Scophthalmus maximus L.), halibut (Hippoglossus hippoglossus L.) and sea bream (Sparus aurata L.). Aquacult. Nutr., 8(3): 195203.

Tocher, D.R., Mourente, G., Van Der Eecken, A., Evjemo, J.O., Diaz, E., Wille, M., Bell, J.G. and Olsen, Y. (2002b). Comparative study of antioxidant defence mechanism in marine fish fed variable levels of oxidised oil and vitamin E. Aquacult. Int., 11(1-2): 196216.

Ways, P. and Hanahan, DJ. (1964). Characterization and quantification of red cell lipids in normal man. J. Lipids Res., 5: 318-328.

Yin, M.C. and Blaxter, H.S. (1987). Temperature, salinity tolerance, and buoyancy during early development and starvation of Clyde and North Sea herring cod and flounder larvae. J. Exp. Mar. Biol. Ecol., 10: 279-290. 